\title{
Paenibacillus sputi sp. nov., isolated from the sputum of a patient with pulmonary disease
}

Correspondence Jung-Sook Lee jslee@kribb.re.kr

\author{
Kwang Kyu Kim, ${ }^{1}$ Keun Chul Lee, ${ }^{1}$ Heekyung Yu, ${ }^{2}$ Sungweon Ryoo, ${ }^{2}$ \\ Youngkil Park ${ }^{2}$ and Jung-Sook Lee ${ }^{1}$
}

\author{
${ }^{1}$ Korean Collection for Type Cultures, Biological Resource Center, Korea Research Institute of \\ Bioscience and Biotechnology, 52 Eoeun-dong, Yuseong-gu, Daejeon 305-806, Republic of \\ Korea \\ ${ }^{2}$ Korean Institute of Tuberculosis, 14 Woomyun-dong, Socho-gu, Seoul 137-900, Republic of \\ Korea
}

Strain KIT 00200-70066-1 ${ }^{\top}$ was isolated from the sputum of a patient with pulmonary disease. Cells of the strain were Gram-variable, facultatively anaerobic, motile, spore-forming rods and formed colourless to white colonies on tryptic soy agar at $30{ }^{\circ} \mathrm{C}$ and $\mathrm{pH}$. The pathogenicity of the strain is not known. The strain contained meso-diaminopimelic acid as the diagnostic diamino acid in the cell-wall peptidoglycan, MK-7 as the predominant menaquinone, anteiso- $\mathrm{C}_{15: 0 \text {, }}$ iso- $\mathrm{C}_{16: 0}$ and $\mathrm{C}_{16: 0}$ as the major fatty acids and diphosphatidylglycerol, phosphatidylglycerol, phosphatidylethanolamine and several unknown lipids in the polar lipid profile. Phylogenetic analysis based on 16S rRNA gene sequences showed that the isolate belongs to the genus Paenibacillus, sharing the highest levels of sequence similarity with Paenibacillus nanensis MX2$3^{\top}$, Paenibacillus agaridevorans DSM $1355^{\top}$ and Paenibacillus alkaliterrae KSL-134 ${ }^{\top}(95.4,95.2$ and $94.8 \%$, respectively), and that it occupied a distinct position within this genus. Combined phylogenetic and phenotypic data supported the conclusion that strain KIT 00200-70066-1 ${ }^{\top}$ represents a novel species of the genus Paenibacillus, for which the name Paenibacillus sputisp.

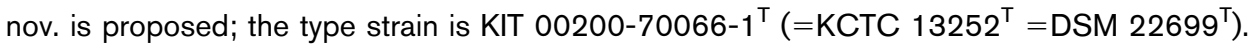

The genus Paenibacillus (type species, Paenibacillus polymyxa) was erected by Ash et al. (1993) to accommodate the so-called rRNA group 3 bacilli, comprising 11 Bacillus species, on the basis of comparative $16 \mathrm{~S}$ rRNA gene sequence analysis. Since then, eight more Bacillus species and one Clostridium species have been transferred to the genus, and a large number of novel species have been described; consequently, the genus contains 102 recognized species at the time of writing (Euzéby, 2009). Members of the genus Paenibacillus have been isolated from a wide variety of sources including soil, sediment, humus, the plant rhizosphere and phyllosphere, water, food, fodder, faeces, plant materials and diseased insect larvae (Daane et al., 2002). Some species have been reported from human biological samples, e.g. Paenibacillus turicensis and Paenibacillus provencensis from cerebrospinal fluid samples, Paenibacillus massiliensis, Paenibacillus sanguinis, Paenibacillus timonensis and Paenibacillus konsidensis from blood cultures and Paenibacillus urinalis from a urine sample,

The GenBank/EMBL/DDBJ accession number for the 16S rRNA gene sequence of strain KIT 00200-70066- $1^{\top}$ is FN394513.

Transmission electron micrographs, a maximum-parsimony tree and an extended neighbour-joining tree based on 16S rRNA gene sequences and results of 2D TLC of polar lipids are available as supplementary material with the online version of this paper. but they have been considered to be contaminants rather than pathogens (Bosshard et al., 2002; Roux \& Raoult, 2004; Ko et al., 2008; Roux et al., 2008). Meanwhile, it has been reported that some pathogenic strains considered to belong to Paenibacills alvei and Paenibacillus macerans were isolated from patients with brain abscesses, catheter-associated infections, endophthalmitis, meningitis, prosthetic hip infections and wound infections (Antonello \& Weinstein, 1989; Reboli et al., 1989; Bert et al., 1995; Barrero et al., 1996). However, they were classified based only on conventional phenotypic characterization, so their taxonomic affiliation remains uncertain.

In 2006, strain KIT 00200-70066-1 ${ }^{\mathrm{T}}$ was co-isolated from the sputum of a 60 -year-old male patient during the screening of mycobacteria from patients with nontuberculous pulmonary diseases. On the basis of preliminary $16 \mathrm{~S}$ rRNA gene sequence comparison, the strain was found to belong to the genus Paenibacillus, but it showed low levels of $16 \mathrm{~S}$ rRNA gene sequence similarity (<96\%) to all recognized species of this genus. To elucidate the taxonomic status of the isolate further, it was subjected to a polyphasic taxonomic investigation.

A sputum sample from the patient was diluted serially in $0.85 \%$ saline solution. Aliquots of each serial dilution were 
spread on Löwenstein-Jensen medium and incubated at $37{ }^{\circ} \mathrm{C}$ for 4 weeks. A white and glistening colony, designated KIT $00200-70066-1^{\mathrm{T}}$, was isolated. The isolate was subcultured onto tryptic soy agar (TSA; Difco) at $37{ }^{\circ} \mathrm{C}$ for 4 days. For most experiments including fatty acid analysis, strain KIT 00200-70066- $1^{\mathrm{T}}$ was cultured on TSA at $30{ }^{\circ} \mathrm{C}$ for 2 days. Paenibacillus nanensis KCTC $13044^{\mathrm{T}}$, Paenibacillus agaridevorans KCTC $3849^{\mathrm{T}}$ and Paenibacillus alkaliterrae KCTC $3956^{\mathrm{T}}$, grown under identical conditions, were used as reference strains for fatty acid analysis and other phenotypic tests.

The Gram reaction was assessed as described by Gerhardt et al. (1994). Cell morphology and motility were observed under a light microscope $(\times 1500$ magnification; Nikon Optiphot-2) with cells grown for 1-7 days. Motility was tested using the hanging-drop technique (Skerman, 1967). For the observation of flagella and endospores, cells were negatively stained with $1 \%(\mathrm{w} / \mathrm{v})$ uranyl acetate and examined using a model H-7600 transmission electron microscope (Hitachi); thin sections of cells were prepared as described by Paster \& Canale-Parola (1982). Oxidase activity was tested using Bactident oxidase strips (Merck) and catalase activity was tested using $3 \% \mathrm{H}_{2} \mathrm{O}_{2}$. Growth was investigated at $5,10,15,20,25,30,37,42,45$ and $50{ }^{\circ} \mathrm{C}$, in the presence of $1,2,3,5,6.5$ and $10 \% \mathrm{NaCl}$ and at $\mathrm{pH}$ 5-11 (in increments of $1 \mathrm{pH}$ unit). Anaerobic growth was examined on TSA or on TSA supplemented with nitrate incubated in a jar with the GasPak Anaerobic System (BBL). Growth on MacConkey agar and cetrimide agar (Difco) was also investigated. Hydrolysis of casein, DNA, starch and tyrosine was tested on casein agar, DNase test agar, starch agar and tyrosine agar (BBL), respectively. Hydrolysis of Tween 80 was tested on Tween 80 agar (DSMZ medium no. 884). The production of lecithinase and lipase was detected on egg-yolk agar (McClung \& Toabe, 1947). Haemolysis was studied on TSA supplemented with $5 \%(\mathrm{v} / \mathrm{v})$ sheep blood. $\mathrm{H}_{2} \mathrm{~S}$ production was tested in tryptic soy broth (Difco) supplemented with $0.01 \%(\mathrm{w} / \mathrm{v})$ cysteine, with a strip of lead acetate paper (Fluka) as an indicator. The methyl red and VogesProskauer tests were performed in MR-VP broth (BBL). Single carbon source assimilation tests were performed in mineral salts basal medium (Stanier et al., 1966) supplemented with $1 \%(\mathrm{v} / \mathrm{v})$ vitamin solution (Staley, 1968). Filter-sterilized substrate $(0.1 \%, \mathrm{w} / \mathrm{v})$ was added to this medium, with the exception of carbohydrates, which were used at $0.2 \%(\mathrm{w} / \mathrm{v})$. The organic compounds tested as sole sources of carbon and energy were acetate, $\mathrm{N}$-acetylglucosamine, L-alanine, amygdalin, L-arabinose, L-arabitol, cellobiose, citrate, D-fructose, L-fucose, D-galactose, gentiobiose, gluconate, D-glucose, glycerol, glycogen, L-histidine, inositol, DL-lactate, lactose, malate, malonate, maltose, D-mannitol, D-mannose, melezitose, melibiose, L-proline, propionate, raffinose, L-rhamnose, D-ribose, D-salicin, L-serine, Dsorbitol, starch, sucrose, trehalose, turanose and D-xylose. Acid production tests, enzyme activity tests and additional phenotypic tests were performed using API 20E, API 20NE,
API 50CH (with $\mathrm{CHB} / \mathrm{E}$ medium) and API ZYM galleries according to the instructions of the manufacturer (bioMérieux). Duplicate antibiotic-susceptibility tests were performed using Sensi-Discs (6 mm; BBL) containing the following: ampicillin $(10 \mu \mathrm{g})$, chloramphenicol $(30 \mu \mathrm{g})$, erythromycin $(15 \mu \mathrm{g})$, kanamycin $(30 \mu \mathrm{g})$, neomycin $(30 \mu \mathrm{g})$, penicillin $\mathrm{G}(10 \mathrm{IU})$, rifampicin $(5 \mu \mathrm{g})$, streptomycin $(10 \mu \mathrm{g})$, tetracycline $(30 \mu \mathrm{g})$, ticarcillin/clavulanic acid $(75 \mu \mathrm{g} / 10 \mu \mathrm{g})$ and vancomycin $(30 \mu \mathrm{g})$; zone diameter interpretive standards for staphylococci of the NCCLS (2003) were used for interpretation.

Fatty acid methyl esters were prepared and analysed as described by Klatte et al. (1994) by using the standard Microbial Identification System (MIDI Inc.) for automated gas chromatographic analysis (Sasser, 1990; Kämpfer \& Kroppenstedt, 1996). Isoprenoid quinones were extracted with chloroform/methanol $(2: 1, \mathrm{v} / \mathrm{v})$ and purified by using TLC on Kieselgel $60 \mathrm{~F}_{254}$ plates $(20 \times 20 \mathrm{~cm}, 0.5 \mathrm{~mm}$ thickness; Merck) with petroleum ether/diethyl ether (9:1, $\mathrm{v} / \mathrm{v}$ ) as the solvent. The quinones were identified by using reversed-phase HPLC analysis, as described by Shin et al. (1996). The diamino acid of the peptidoglycan was determined by using TLC as described by Staneck \& Roberts (1974). Polar lipids were extracted, examined by using two-dimensional TLC and identified according to published procedures (Minnikin et al., 1977).

Extraction of genomic DNA, PCR-mediated amplification of the 16S rRNA gene and sequencing of the purified PCR product were carried out according to Rainey et al. (1996). The 16S rRNA gene sequence was aligned with published sequences retrieved from GenBank/EMBL/DDBJ using CLUSTAL_X (Thompson et al., 1997) and edited via the BioEdit program (Hall, 1999). Phylogenetic trees were constructed on the basis of the neighbour-joining (Saitou \& Nei, 1987) and maximum-parsimony (Fitch, 1971) methods; distances were estimated by the method of Jukes \& Cantor (1969) using MEGA version 4.0 (Tamura et al., 2007). The resultant tree topologies were evaluated by bootstrap analysis (Felsenstein, 1985) based on 1000 resampled datasets. DNA G $+\mathrm{C}$ contents were determined by using HPLC, following hydrolysis, as described by Tamaoka \& Komagata (1984), and non-methylated $\lambda$ phage DNA (Sigma) was used as a standard.

Strain KIT 00200-70066- $1^{\mathrm{T}}$ formed visible colonies (about 1-2 $\mathrm{mm}$ in diameter) within 2 days on TSA incubated at $30{ }^{\circ} \mathrm{C}$. Good growth occurred at $25-37{ }^{\circ} \mathrm{C}$. The colonies were colourless to white, translucent and circular to slightly irregular and became mucoid after prolonged incubation. Cells were Gram-variable, facultatively anaerobic, motile rods with peritrichous flagella. Ellipsoidal subterminal spores were formed in swollen sporangia. Transmission electron micrographs of cells of strain KIT 00200-70066-1 ${ }^{\mathrm{T}}$ are available as Supplementary Fig. S1 in IJSEM Online.

An almost-complete 16S rRNA gene sequence (1457 nt) of strain KIT 00200-70066- $1^{\mathrm{T}}$ was determined and compared with those of all known species of the genus Paenibacillus. 
Strain KIT 00200-70066-1 ${ }^{\mathrm{T}}$ showed the highest levels of sequence similarity with $P$. nanensis $\mathrm{MX} 2-3^{\mathrm{T}}$, $P$. agaridevorans DSM $1355^{\mathrm{T}}$ and $P$. alkaliterrae KSL-134 $4^{\mathrm{T}}$, with values of $95.4,95.2$ and $94.8 \%$, respectively. In the neighbour-joining tree (Fig. 1), strain KIT 00200-70066$1^{\mathrm{T}}$ formed a separate lineage within the genus Paenibacillus, while it formed a clade with $P$. nanensis $\mathrm{MX} 2-3^{\mathrm{T}}$ and $P$. agaridevorans DSM $1355^{\mathrm{T}}$ in the maximum-parsimony tree (Supplementary Fig. S2), which was poorly supported by bootstrap analysis. Consequently, strain KIT 00200-70066$1^{\mathrm{T}}$ occupied quite a distinct position with respect to its phylogenetic neighbours within the genus Paenibacillus. An extended 16S rRNA gene sequence-based neighbour-joining tree is available as Supplementary Fig. S3.

The morphological, physiological, biochemical and chemotaxonomic characteristics of strain KIT 00200-70066- $1^{\mathrm{T}}$ are given in the species description; those that serve to differentiate it from related taxa are listed in Table 1. Strain KIT 00200-70066-1 $1^{\mathrm{T}}$ was distinguished from related taxa by differences in colony colour, Gram stain reaction, cell size, temperature range for growth, lipase activity on eggyolk agar, hydrolysis of L-leucyl 2-naphthylamide and 2naphthyl phosphate ( $\mathrm{pH}$ 5.4) and susceptibility to kanamycin as well as by differences in acid production and substrate utilization profiles. Strain KIT 00200-70066- ${ }^{\mathrm{T}}$ showed a fatty acid profile similar to those of related taxa, i.e. the fatty acids anteiso- $\mathrm{C}_{15: 0}$, iso- $\mathrm{C}_{16: 0}$ and $\mathrm{C}_{16: 0}$ were predominant (Table 2), and contained meso-diaminopimelic acid as the diagnostic diamino acid in the cell-wall peptidoglycan, diphosphatidylglycerol, phosphatidylglycerol, phosphatidylethanolamine and several unknown lipids in the polar lipid profile (Supplementary Fig. S4) and menaquinone MK-7 as the major isoprenoid quinone.

Strain KIT 00200-70066- ${ }^{\mathrm{T}}$ was isolated from the sputum of a patient suffering from pulmonary disease. However, its clinical significance could not be determined because no sign or symptom of serious infection developed in the patient. Whether it was an opportunistic pathogen or a contaminant, strain KIT 00200-70066-1 ${ }^{\mathrm{T}}$ was worth studying in that, to our knowledge, it was the first Paenibacillus strain to be isolated from human sputum.

On the basis of the 16S rRNA gene dissimilarity with respect to related taxa, together with the phylogenetically distinct position and unique phenotypic characteristics, strain KIT 00200-70066-1 $1^{\mathrm{T}}$ merits recognition as a representative of a novel species within the genus Paenibacillus, for which the name Paenibacillus sputi sp. nov. is proposed.

\section{Description of Paenibacillus sputi sp. nov.}

Paenibacillus sputi (spu'ti. L. gen. n. sputi of sputum).

Cells are Gram-variable, facultatively anaerobic rods (0.5$0.6 \times 2.0-3.0 \mu \mathrm{m})$. Motile by means of peritrichous flagella. Ellipsoidal subterminal spores are formed in swollen sporangia. Forms colourless to white, translucent, mucoid colonies on TSA. Catalase- and oxidase-positive. Growth occurs at $15-42{ }^{\circ} \mathrm{C}$ (optimum $30-37{ }^{\circ} \mathrm{C}$ ) and at $\mathrm{pH}$ 6-9 (optimum pH 7). Growth occurs in the presence of up to $3 \% \mathrm{NaCl}$, but not with $5 \% \mathrm{NaCl}$. Anaerobic growth is observed, regardless of the presence of nitrate. Indole is not produced. No growth is observed on MacConkey agar or cetrimide agar. $\mathrm{H}_{2} \mathrm{~S}$ is produced from L-cysteine, but not from thiosulfate. Nitrate is not reduced. The methyl red test is negative, but the Voges-Proskauer test is positive. On $5 \%$ sheep blood agar, $\alpha$-haemolysis is observed. Aesculin, starch and Tween 80 are hydrolysed, but casein, DNA, gelatin and tyrosine are not. $\beta$-Galactosidase is produced, but arginine dihydrolase, lysine decarboxylase, ornithine decarboxylase, phenylalanine deaminase and urease are not. On egg-yolk agar, lipase activity is present, but lecithinase activity is absent. L-Arabinose, cellobiose, Dgalactose, D-glucose, glycogen, lactose, maltose, L-rhamnose, D-salicin, starch and D-xylose are utilized as sole sources of carbon and energy, but acetate, $\mathrm{N}$-acetylglucosamine, L-alanine, amygdalin, L-arabitol, citrate, D-fructose,

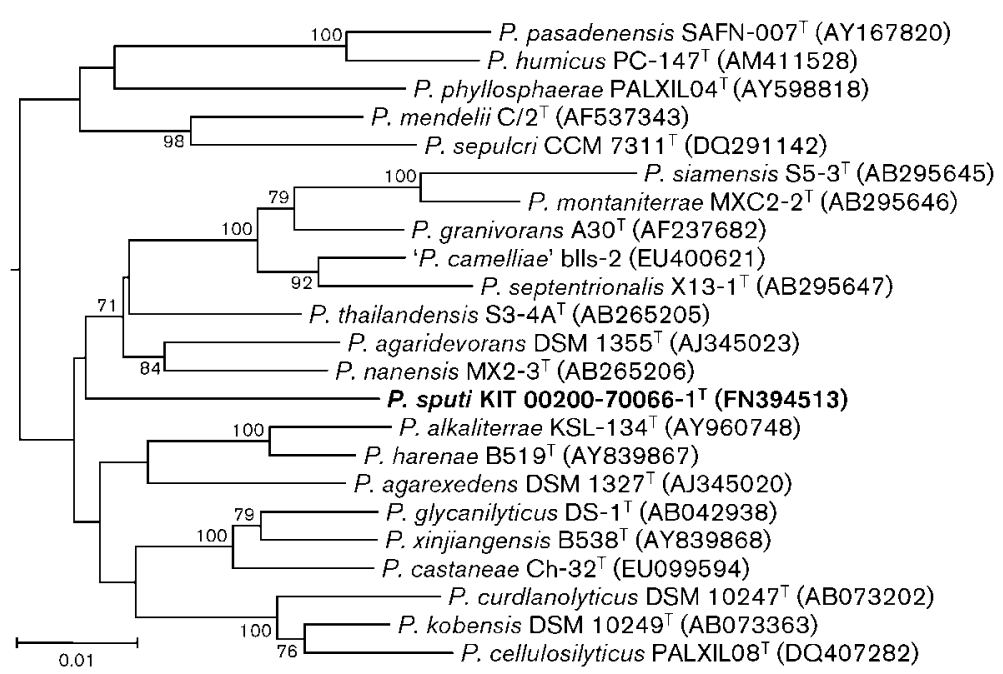

Fig. 1. Phylogenetic tree based on $16 \mathrm{~S}$ rRNA gene sequences, constructed with the neighbour-joining method, showing the position of strain KIT 00200-70066-1 ${ }^{\top}$ among members of the genus Paenibacillus. Percentages at nodes are levels of bootstrap support $(\geqslant 50 \%)$ based on 1000 resamplings. Bar, 0.01 substitutions per nucleotide position. 
Table 1. Phenotypic characteristics that differentiate strain KIT 00200-70066-1 ${ }^{\top}$ from the type strains of related Paenibacillus species

Strains: 1 , Paenibacillus sputi sp. nov. KIT 00200-70066-1 ${ }^{\mathrm{T}}$; 2, P. nanensis $\mathrm{KCTC} 13044^{\mathrm{T}} ; 3$, P. agaridevorans KCTC $3849^{\mathrm{T}}$; 4, P. alkaliterrae KCTC $3956^{\mathrm{T}}$. Data were obtained in this study unless indicated. All strains were positive for catalase and oxidase activity and showed $\alpha$-haemolysis. + , Positive; - , negative; v, variable; NA, no data available.

\begin{tabular}{|c|c|c|c|c|}
\hline Characteristic & 1 & 2 & 3 & 4 \\
\hline Colony colour ${ }^{*}$ & $\mathrm{C} / \mathrm{WH}$ & wH & WH & I \\
\hline Gram stain & V & + & $\mathrm{V} /-$ & + \\
\hline Cell length $(\mu \mathrm{m})$ & $2.0-3.0$ & $3.0-8.0^{a} \dagger$ & $2.0-5.0^{b}$ & $1.5-3.0^{c}$ \\
\hline Cell width $(\mu \mathrm{m})$ & $0.5-0.6$ & $1.0-1.2^{a}$ & $0.6-0.8^{b}$ & $0.4-0.5^{c}$ \\
\hline Flagellar arrangement $\ddagger$ & $\mathrm{Pe}$ & $\mathrm{Pe}^{a}$ & NA & $\mathrm{P}^{c}$ \\
\hline Anaerobic growth & + & + & - & - \\
\hline Temperature range for growth $\left({ }^{\circ} \mathrm{C}\right)$ & $15-42$ & $20-45$ & $10-42$ & $10-37$ \\
\hline Voges-Proskauer test & + & + & - & - \\
\hline Nitrate reduction & - & + & - & + \\
\hline Lipase on egg-yolk agar & + & - & - & - \\
\hline \multicolumn{5}{|l|}{ Acid production from: } \\
\hline $\mathrm{N}$-Acetylglucosamine & + & - & - & - \\
\hline D-Arabinose & + & - & - & + \\
\hline L-Fucose & + & - & - & - \\
\hline D-Ribose & + & - & - & - \\
\hline Sucrose & - & + & + & + \\
\hline Trehalose & - & + & + & + \\
\hline \multicolumn{5}{|l|}{ Growth on: } \\
\hline D-Fructose & - & + & - & + \\
\hline Gentiobiose & - & + & + & - \\
\hline Glycerol & - & + & + & - \\
\hline D-Mannose & - & + & - & + \\
\hline Melibiose & - & + & + & + \\
\hline L-Rhamnose & + & - & - & - \\
\hline \multicolumn{5}{|l|}{ Hydrolysis of: } \\
\hline L-Leucyl 2-naphthylamide & + & - & - & - \\
\hline 2-Naphthyl phosphate (pH 5.4) & + & - & - & - \\
\hline 6-Bromo-2-naphthyl $\alpha$-D-galactopyranoside & - & + & - & + \\
\hline 2-Naphthyl $\alpha$-D-glucopyranoside & - & + & - & + \\
\hline 6-Bromo-2-naphthyl $\beta$-D-glucopyranoside & - & + & - & + \\
\hline \multicolumn{5}{|l|}{ Susceptibility to: } \\
\hline Chloramphenicol & + & - & - & + \\
\hline Kanamycin & - & + & + & + \\
\hline Streptomycin & + & - & - & + \\
\hline DNA G $+\mathrm{C}$ content $(\mathrm{mol} \%)$ & 48.1 & 53.5 & 50.1 & 49.8 \\
\hline
\end{tabular}

${ }^{*} \mathrm{C}$, Colourless; I, ivory; wH, white.

$\dagger$ Data taken from: $a$, Khianngam et al. (2009); b, Uetanabaro et al. (2003); c, Yoon et al. (2005).

$\ddagger \mathrm{P}$, Polar; Pe, peritrichous.

L-fucose, gentiobiose, gluconate, glycerol, L-histidine, myoinositol, DL-lactate, malate, malonate, D-mannitol, Dmannose, melezitose, melibiose, L-proline, propionate, raffinose, D-ribose, L-serine, D-sorbitol, sucrose, trehalose and turanose are not. In the API $50 \mathrm{CH}$ gallery, acid is produced from $\mathrm{N}$-acetylglucosamine, amygdalin, D- and Larabinose, cellobiose, aesculin, L-fucose, D-galactose, Dglucose, glycogen, lactose, maltose, D-mannose, melibiose, methyl $\alpha$-D-glucoside, methyl $\beta$-D-xylose, raffinose, $\mathrm{L}$ - rhamnose, D-ribose, D-salicin, starch and D-xylose, but not from D-adonitol, D- or L-arabitol, arbutin, dulcitol, erythritol, D-fructose, D-fucose, gentiobiose, gluconate, glycerol, inositol, inulin, 2- or 5-ketogluconate, D-lyxose, D-mannitol, melezitose, methyl $\alpha$-D-mannoside, D-sorbitol, L-sorbose, sucrose, D-tagatose, trehalose, turanose, xylitol or L-xylose. According to the results from API ZYM tests, L-leucyl 2-naphthylamide, 2-naphthyl butyrate, 2naphthyl $\beta$-D-galactopyranoside and 2-naphthyl phosphate 
Table 2. Cellular fatty acid compositions (\%) of strain KIT 00200-70066 $-1^{\top}$ and the type strains of related Paenibacillus species

Strains: 1, P. sputi sp. nov. KIT 00200-70066-1 ${ }^{\mathrm{T}}$; 2, P. nanensis KCTC $13044^{\mathrm{T}}$; 3, P. agaridevorans KCTC $3849^{\mathrm{T}}$; 4, P. alkaliterrae KCTC $3956^{\mathrm{T}}$. Data were obtained in this study. Fatty acids are listed using standard abbreviations (number of carbon atoms : number of double bonds). ND, Not detected; tr, trace $(<0.5 \%)$.

\begin{tabular}{|lcccc|}
\hline Fatty acid & $\mathbf{1}$ & $\mathbf{2}$ & $\mathbf{3}$ & $\mathbf{4}$ \\
\hline Saturated straight-chain & & & & \\
$\mathrm{C}_{14: 0}$ & 0.9 & 0.7 & 1.0 & 1.6 \\
$\mathrm{C}_{15: 0}$ & 8.5 & 2.1 & 4.4 & 1.4 \\
$\mathrm{C}_{16: 0}$ & 15.7 & 13.0 & 9.3 & 16.8 \\
$\mathrm{C}_{17: 0}$ & 1.9 & 0.6 & 0.7 & $\operatorname{tr}$ \\
$\mathrm{C}_{18: 0}$ & $\mathrm{ND}$ & $\operatorname{tr}$ & $\mathrm{ND}$ & 0.5 \\
Saturated branched & & & & \\
iso- $\mathrm{C}_{14: 0}$ & 3.7 & 1.9 & 6.0 & 3.9 \\
iso-- $\mathrm{C}_{15: 0}$ & 6.4 & 5.6 & 7.3 & 7.8 \\
iso- $\mathrm{C}_{16: 0}$ & 16.5 & 17.9 & 19.8 & 15.2 \\
iso-C $17: 0$ & 3.7 & 5.5 & 3.4 & 3.4 \\
iso- $\mathrm{C}_{18: 0}$ & $\operatorname{tr}$ & $\operatorname{tr}$ & $\mathrm{ND}$ & $\mathrm{ND}$ \\
anteiso-C & & \\
anteiso- $\mathrm{C}_{17: 0}$ & 37.7 & 42.8 & 43.4 & 43.4 \\
Unsaturated & 4.1 & 9.2 & 4.2 & 5.5 \\
$\mathrm{C}_{16: 1} \omega 11 c$ & & & & \\
\hline
\end{tabular}

(pH 5.4) are hydrolysed, but $N$-benzoyl-DL-arginine 2naphthylamide, 6-bromo-2-naphthyl $\alpha$-D-galactopyranoside, 6-bromo-2-naphthyl $\beta$-D-glucopyranoside, 6-bromo-2naphthyl $\alpha$-D-mannopyranoside, L-cystyl 2-naphthylamide, $\mathrm{N}$-glutaryl-phenylalanine 2-naphthylamide, naphthol-AS-BI$\beta$-D-glucuronide, naphthol-AS-BI-phosphate, 1-naphthyl $N$ acetyl- $\beta$-D-glucosaminide, 2-naphthyl caprylate, 2-naphthyl $\alpha$-L-fucopyranoside, 2 -naphthyl $\alpha$-D-glucopyranoside, 2 naphthyl myristate, 2-naphthyl phosphate ( $\mathrm{pH} 8.5)$ and Lvalyl 2-naphthylamide are not. Susceptible to ampicillin, chloramphenicol, erythromycin, neomycin, penicillin G, rifampicin, streptomycin, tetracycline, trimethoprim/sulfamethoxazole and vancomycin. Resistant to kanamycin. The cell-wall peptidoglycan contains meso-diaminopimelic acid. The major isoprenoid quinone is MK-7. The fatty acids anteiso- $\mathrm{C}_{15: 0}$, iso- $\mathrm{C}_{16: 0}$ and $\mathrm{C}_{16: 0}$ are predominant. The major cellular phospholipids are diphosphatidylglycerol, phosphatidylglycerol and phosphatidylethanolamine. The $\mathrm{G}+\mathrm{C}$ content of the DNA of the type strain is $48.1 \mathrm{~mol} \%$.

The type strain is KIT 00200-70066- ${ }^{\mathrm{T}}\left(=\right.$ KCTC $13252^{\mathrm{T}}$ $=$ DSM $22699^{\mathrm{T}}$ ), isolated from the sputum of a patient.

\section{Acknowledgements}

This work was supported by a grant from the KRIBB Research Initiative Program and by a grant from the Ministry of Education, Science and Technology (MEST) of the Republic of Korea (no. M10437010001).

\section{References}

Antonello, A. \& Weinstein, G. W. (1989). Successful treatment of Bacillus alvei endophthalmitis. Am J Ophthalmol 108, 454-455.

Ash, C., Priest, F. G. \& Collins, D. C. (1993). Molecular identification of rRNA group 3 bacilli (Ash, Farrow, Wallbanks and Collins) using a PCR probe test. Proposal for the creation of a new genus Paenibacillus. Antonie van Leeuwenhoek 64, 253-260.

Barrero, F., Galán, F., Marín, P., García-Martos, P. \& Capote, F. J. (1996). Catheter associated infection by Bacillus macerans in a patient with acute leukemia. Enferm Infecc Microbiol Clin 14, 628-629.

Bert, F., Ouahes, O. \& Lambert-Zechovsky, N. (1995). Brain abscess due to Bacillus macerans following a penetrating periorbital injury. J Clin Microbiol 33, 1950-1953.

Bosshard, P. P., Zbinden, R. \& Altwegg, M. (2002). Paenibacillus turicensis sp. nov., a novel bacterium harbouring heterogeneities between 16S rRNA genes. Int J Syst Evol Microbiol 52, 2241-2249.

Daane, L. L., Harjono, I., Barns, S. M., Launen, L. A., Palleroni, N. J. \& Häggblom, M. M. (2002). PAH-degradation by Paenibacillus spp. and description of Paenibacillus naphthalenovorans sp. nov., a naphthalene-degrading bacterium from the rhizosphere of salt marsh plants. Int J Syst Evol Microbiol 52, 131-139.

Euzéby, J. P. (2009). List of Prokaryotic Names with Standing in Nomenclature. http://www.bacterio.cict.fr/

Felsenstein, J. (1985). Confidence limits on phylogenies: an approach using the bootstrap. Evolution 39, 783-791.

Fitch, W. M. (1971). Toward defining the course of evolution: minimum change for a specific tree topology. Syst Zool 20, 406-416.

Gerhardt, P., Murray, R. G. E., Wood, W. A. \& Krieg, N. R. (editors) (1994). Methods for General and Molecular Bacteriology. Washington, DC: American Society for Microbiology.

Hall, T. A. (1999). BioEdit: a user-friendly biological sequence alignment editor and analysis program for Windows 95/98/NT. Nucleic Acids Symp Ser 41, 95-98.

Jukes, T. H. \& Cantor, C. R. (1969). Evolution of protein molecules. In Mammalian Protein Metabolism, vol. 3, pp. 21-132. Edited by H. N. Munro. New York: Academic Press.

Kämpfer, P. \& Kroppenstedt, R. M. (1996). Numerical analysis of fatty acid patterns of coryneform bacteria and related taxa. Can $J$ Microbiol 42, 989-1005.

Khianngam, S., Akaracharanya, A., Tanasupawat, S., Lee, K. C. \& Lee, J.-S. (2009). Paenibacillus thailandensis sp. nov. and Paenibacillus nanensis sp. nov., xylanase-producing bacteria isolated from soil. Int $J$ Syst Evol Microbiol 59, 564-568.

Klatte, S., Rainey, F. A. \& Kroppenstedt, R. M. (1994). Transfer of Rhodococcus aichiensis Tsukamura 1982 and Nocardia amarae Lechevalier and Lechevalier 1974 to the genus Gordona as Gordona aichiensis comb. nov. and Gordona amarae comb. nov. Int J Syst Bacteriol 44, 769-773.

Ko, K. S., Kim, Y.-S., Lee, M. Y., Shin, S. Y., Jung, D. S., Peck, K. R. \& Song, J.-H. (2008). Paenibacillus konsidensis sp. nov., isolated from a patient. Int J Syst Evol Microbiol 58, 2164-2168.

McClung, L. S. \& Toabe, R. (1947). The egg yolk plate reaction for the presumptive diagnosis of Clostridium sporogenes and certain species of the gangrene and botulinum groups. J Bacteriol 53, 139-147.

Minnikin, D. E., Patel, P. V., Alshamaony, L. \& Goodfellow, M. (1977). Polar lipid composition in the classification of Nocardia and related bacteria. Int J Syst Bacteriol 27, 104-117.

NCCLS (2003). Performance standards for antimicrobial disk susceptibility tests, 8th edn. Approved Standard, M2-A8. Wayne, PA: National Committee for Clinical Laboratory Standards. 
Paster, B. J. \& Canale-Parola, E. (1982). Physiological diversity of rumen spirochetes. Appl Environ Microbiol 43, 686-693.

Rainey, F. A., Ward-Rainey, N., Kroppenstedt, R. M. \& Stackebrandt, E. (1996). The genus Nocardiopsis represents a phylogenetically coherent taxon and a distinct actinomycete lineage: proposal of Nocardiopsaceae fam. nov. Int J Syst Bacteriol 46, 1088-1092.

Reboli, A. C., Bryan, C. S. \& Farrar, W. E. (1989). Bacteremia and infection of a hip prosthesis caused by Bacillus alvei. J Clin Microbiol 27, 1395-1396.

Roux, V. \& Raoult, D. (2004). Paenibacillus massiliensis sp. nov., Paenibacillus sanguinis sp. nov. and Paenibacillus timonensis sp. nov., isolated from blood cultures. Int J Syst Evol Microbiol 54, 1049-1054.

Roux, V., Fenner, L. \& Raoult, D. (2008). Paenibacillus provencensis sp. nov., isolated from human cerebrospinal fluid, and Paenibacillus urinalis sp. nov., isolated from human urine. Int J Syst Evol Microbiol 58, 682-687.

Saitou, N. \& Nei, M. (1987). The neighbor-joining method: a new method for reconstructing phylogenetic trees. Mol Biol Evol 4, 406-425.

Sasser, M. (1990). Identification of bacteria by gas chromatography of cellular fatty acids, MIDI Technical Note 101. Newark, DE: MIDI Inc.

Shin, Y. K., Lee, J.-S., Chun, C. O., Kim, H.-J. \& Park, Y.-H. (1996). Isoprenoid quinone profiles of Leclercia adecarboxylata KCTC $1036^{\mathrm{T}}$. J Microbiol Biotechnol 6, 68-69.

Skerman, V. B. D. (1967). A Guide to the Identification of the Genera of Bacteria, 2nd edn. Baltimore: Williams \& Wilkins.
Staley, J. T. (1968). Prosthecomicrobium and Ancalomicrobium: new prosthecate freshwater bacteria. J Bacteriol 95, 1921-1942.

Staneck, J. L. \& Roberts, G. D. (1974). Simplified approach to identification of aerobic actinomycetes by thin layer chromatography. Appl Microbiol 28, 226-231.

Stanier, R. Y., Palleroni, N. J. \& Doudoroff, M. (1966). The aerobic pseudomonads: a taxonomic study. J Gen Microbiol 43, 159-271.

Tamaoka, J. \& Komagata, K. (1984). Determination of DNA base composition by reversed-phase high-performance liquid chromatography. FEMS Microbiol Lett 25, 125-128.

Tamura, K., Dudley, J., Nei, M. \& Kumar, S. (2007). MEGA4: molecular evolutionary genetics analysis (MEGA) software version 4.0. Mol Biol Evol 24, 1596-1599.

Thompson, J. D., Gibson, T. J., Plewniak, F., Jeanmougin, F. \& Higgins, D. G. (1997). The CLUSTAL_X windows interface: flexible strategies for multiple sequence alignment aided by quality analysis tools. Nucleic Acids Res 25, 4876-4882.

Uetanabaro, A. P., Wahrenburg, C., Hunger, W., Pukall, R., Spröer, C., Stackebrandt, E., de Canhos, V. P., Claus, D. \& Fritze, D. (2003). Paenibacillus agarexedens sp. nov., nom. rev., and Paenibacillus agaridevorans sp. nov. Int J Syst Evol Microbiol 53, 1051-1057.

Yoon, J.-H., Kang, S.-J., Yeo, S.-H. \& Oh, T.-K. (2005). Paenibacillus alkaliterrae sp. nov., isolated from an alkaline soil in Korea. Int J Syst Evol Microbiol 55, 2339-2344. 